University of Nebraska - Lincoln

DigitalCommons@University of Nebraska - Lincoln

Faculty Publications: Department of Entomology

$1-6-2006$

\title{
Stability and persistence of aldrin and methyl-parathion resistance in western corn rootworm populations (Coleoptera: Chrysomelidae)
}

\author{
Srinivas Parimi \\ Maharastra Hybrid Seeds Company Ltd. \\ Lance J. Meinke \\ University of Nebraska-Lincoln, Imeinke1@unl.edu \\ B. Wade French \\ Northern Grain Insects Research Laboratory, USDA-ARS, Wade.French@ars.usda.gov \\ Laurence D. Chandler \\ USDA-ARS \\ Blair D. Siegfried \\ University of Nebraska-Lincoln, bsiegfried1@ufl.edu
}

Follow this and additional works at: https://digitalcommons.unl.edu/entomologyfacpub

Part of the Entomology Commons

Parimi, Srinivas; Meinke, Lance J.; French, B. Wade; Chandler, Laurence D.; and Siegfried, Blair D., "Stability and persistence of aldrin and methyl-parathion resistance in western corn rootworm populations (Coleoptera: Chrysomelidae)" (2006). Faculty Publications: Department of Entomology. 4.

https://digitalcommons.unl.edu/entomologyfacpub/4

This Article is brought to you for free and open access by the Entomology, Department of at DigitalCommons@University of Nebraska - Lincoln. It has been accepted for inclusion in Faculty Publications: Department of Entomology by an authorized administrator of DigitalCommons@University of Nebraska - Lincoln. 


\title{
Stability and persistence of aldrin and methyl-parathion resistance in western corn rootworm populations (Coleoptera: Chrysomelidae)
}

\author{
Srinivas Parimi ${ }^{\mathrm{a}}$, Lance J. Meinke ${ }^{\mathrm{b}}$, B. Wade French ${ }^{\mathrm{c}}$, \\ Laurence D. Chandler ${ }^{\mathrm{d}}$, Blair D. Siegfried ${ }^{\mathrm{b}, *}$ \\ ${ }^{a}$ Maharastra Hybrid Seeds Company Ltd., P.O. Box 76, Jalna 431 203, Maharastra, India \\ ${ }^{\mathrm{b}}$ Department of Entomology, University of Nebraska, Lincoln, NE 68583, USA \\ ${ }^{\mathrm{c}}$ Northern Grain Insects Research Laboratory, USDA-ARS, 2923 Medary Ave., Brookings, SD 57006, USA \\ ${ }^{\mathrm{d}} U S D A-A R S$, Northern Plains Area Office, Fort Collins, CO 80526, USA
}

Received 13 January 2005; received in revised form 27 April 2005; accepted 29 April 2005

\begin{abstract}
The susceptibilities of laboratory and field-collected western corn rootworm populations (Diabrotica virgifera virgifera LeConte) to methyl-parathion and aldrin were estimated by topical application of insecticide during 2002 to determine the stability of resistance in the absence of selective pressures. Most of the laboratory-reared and field-collected populations were significantly resistant to both insecticides. Average $\mathrm{LD}_{50}$ values of laboratory and field-collected populations were 19- and 13-fold greater than the susceptible population in methyl-parathion bioassays, respectively, and 204- and 125-fold greater in the aldrin bioassays, respectively. The presence of aldrin and methyl-parathion resistance in field-collected populations strongly suggests that both resistance traits are stable in the absence of selection pressure and that neither mechanism is associated with a strong fitness disadvantage.
\end{abstract}

(C) 2005 Elsevier Ltd. All rights reserved.

Keywords: Western corn rootworm; Diabrotica; Aldrin; Methyl-parathion; Susceptibility

\section{Introduction}

Cyclodiene insecticides were commonly used as soil treatments for the control of corn rootworms, Diabrotica spp., during the late 1940s to early 1960s. Benzene hexachloride (Muma et al., 1949), aldrin, chlordane (Ball and Hill, 1953) and heptachlor (Ball and Roselle, 1954) were the recommended active ingredients for control of root feeding larvae during this period. Control failures with these compounds were first noted in Nebraska in 1959 (Roselle et al., 1959), and further evaluations in 1960 (Roselle et al., 1960) and 1961

\footnotetext{
*Corresponding author. Tel.: + 14024728714 ; fax: +14024724687 .

E-mail address: bsiegfried1@unl.edu (B.D. Siegfried).
}

(Roselle et al., 1961) revealed the magnitude and rapid development of the resistance.

During 1961, western corn rootworm, Diabrotica virgifera virgifera Leconte, adults were collected from different fields in Nebraska and susceptibility to aldrin and heptachlor was determined by topical application (Ball and Weekman, 1962, 1963). Differences in susceptibility among field populations provided the first evidence of resistance evolution. The development of cyclodiene resistance coincided with a rapid eastward range expansion. By 1980 the distribution of $D . v$. virgifera covered most of the U.S. Corn Belt, including areas where cyclodienes were not widely used as soil insecticides (Metcalf, 1986). Resistance has persisted in populations for many years after the use of these compounds was discontinued (Siegfried and Mullin, 1989). 
After the development of cyclodiene resistance, control recommendations for rootworms shifted to soil application of organophosphates and carbamate insecticides at planting or first cultivation to control rootfeeding larvae (Mayo and Peters, 1978; Ball, 1981). An alternative strategy involving aerial application of insecticides (carbamates and organophosphates) for adult control to reduce egg laying and economic damage from the subsequent generation (Pruess et al., 1974) became widely adopted in certain areas of Nebraska (Meinke et al., 1998). Penncap-M (encapsulated methylparathion) was the most commonly used formulation in the beetle aerial spray programs because of its low price and long residual activity. During the mid-1990s, control failures were first reported in certain areas of Nebraska where adult spray programs were extensively used (Wright et al., 1996). In 1995, Meinke et al. (1998) collected adult western corn rootworms from different locations in Nebraska and performed topical bioassays with methyl-parathion, carbaryl and the pyrethroid insecticide bifenthrin. Their studies confirmed the presence of resistance to methyl-parathion and/or carbaryl but not bifenthrin in adult rootworms from areas of control failure.

The development of resistance to both cyclodienes and methyl-parathion among rootworm populations necessitated dramatic changes in management strategies resulting in vastly reduced selective pressures. In the case of cyclodiene resistance, insecticides with completely different modes of action (i.e., acetylcholinesterase inhibitors) replaced the commonly used cyclodienes $(\gamma$-aminobutyric acid receptor antagonists). These compounds are much less persistent than cyclodienes and, therefore, less likely to cause selection throughout larval development. Additionally, the practice of broadcast application of cyclodienes was replaced by in-furrow or T-band applications such that only a narrow band of the root zone was treated and a significant portion of the rootworm larval population is unexposed. Such a change in chemistry and application technology likely reduced the selective pressure relative to that imposed by broadcast application of cyclodienes.

In the case of methyl-parathion resistance, adult management was largely replaced by crop rotation and soil insecticides (L.J.M., unpublished) in areas where resistance had become widespread. Although some exposure to organophosphates applied as soil insecticides is still likely to occur in these areas, pyrethroids and new chemistries such as the phenylpyrazole insecticide, fipronil, with activity at the $\gamma$-aminobutyric acid receptor, have become more commonly used.

Reduced selection pressures associated with the changes in management practices might be associated with a decline in resistance levels assuming that the resistance results in a substantial fitness cost in the absence of selection (Tabashnik, 1990; McKenzie, 1996).
However, in the case of cyclodiene resistance in western corn rootworms, resistance levels have remained high for up to 20 years (Siegfried and Mullin, 1989), although recent assessments of resistance among field populations are lacking. In the case of methyl-parathion resistance in Nebraska, there has not been a consistent effort to document changes in resistance levels over time, although there has been an indication that resistant populations have expanded in intensity and in distribution, occupying areas where adult management is not commonly practiced (Zhou et al., 2002).

The main objective of the present study was to estimate both aldrin and methyl-parathion susceptibility of field-collected adult western corn rootworm populations from specific areas of Nebraska and from lab populations of resistant beetles reared in the absence of selection. Historical comparisons with previously determined susceptibility levels in populations from similar geographic areas will provide information about the persistence of cyclodiene and methyl-parathion resistance in the absence of selection pressures.

\section{Materials and methods}

\subsection{Insecticides}

Technical grade methyl-parathion (99\% AI) and aldrin $(98 \%$ AI) were purchased from ChemServices Inc. (West Chester, PA). All insecticide dilutions were prepared in reagent grade acetone ( $>99.5 \%$ purity; EM Science, Gibbstown, NJ).

\subsection{Insect populations}

Western corn rootworm populations used for insecticide bioassays were either collected from the field or obtained from laboratory populations. The field populations were collected in 2002 from various sites across Nebraska previously shown to have varying levels of resistance to methyl-parathion based on diagnostic bioassays (Zhou et al., 2002). At least 500 individuals were obtained from each collection site. Laboratory populations were initiated from field-collected adults (at least 200 individuals) during 1995-96 and reared for 7-8 generations at the USDA-ARS Northern Grain Insects Research Laboratory in Brookings, SD, using standard rearing techniques (Jackson et al., 1985). In addition to populations established from Nebraska, laboratory populations originating from Center County, PA and Champaign County, IL were included in the bioassays. The non-diapausing population was initiated from a diapausing colony established in 1968 from fieldcollected beetles near Brookings, SD. After 6 generations of rearing in the laboratory, the non-diapause strain was selected as described by Branson (1976) and 
reared continuously in the absence of exposure to insecticides. Laboratory populations of adult rootworms were shipped from the rearing facility when the sex ratio of emergent beetles approached 1:1 and within $48 \mathrm{~h}$ after emergence. Adult rootworms from both field and laboratory populations were maintained in plexiglass cages at $22-25^{\circ} \mathrm{C}$ and ambient conditions of light and humidity, on fresh sweet corn ears and lettuce, for at least $48 \mathrm{~h}$ prior to insecticide bioassays.

\subsection{Topical bioassays}

Stock solutions of technical grade aldrin and methylparathion were prepared in acetone as $100 \mathrm{mg} / \mathrm{ml}$ and $10 \mathrm{mg} / \mathrm{ml}$ solutions, respectively. Bioassays consisted of four to six insecticide concentrations that produced mortality between $10 \%$ and $100 \%$. Each concentration was replicated 4-6 times with ten unsexed beetles per concentration. Twenty randomly selected beetles from each population were weighed during each bioassay so that the insecticide dose could be calculated based on body weight ( $\mu \mathrm{g}$ insecticide/g body weight). Individual beetles were treated with $0.5 \mu \mathrm{l}$ of methyl-parathion dilution or $1.0 \mu \mathrm{l}$ aldrin dilution applied to the ventral abdomen to be consistent with conditions of previous bioassays. Control beetles were treated with acetone only. Insecticide-treated beetles were placed in Petri plates $(100 \times 15 \mathrm{~mm})$, provided with a moistened dental wick and held at $22^{\circ} \mathrm{C}$ for $24 \mathrm{~h}$ in darkness. Mortality was determined after $24 \mathrm{~h}$ as the lack of coordinated beetle movement.

The topical bioassay data were analyzed by probit analysis (Finney, 1971) using commercially available software (POLO PC, LeOra Software, 1987). The raw data from methyl-parathion topical bioassays reported by Meinke et al. (1998) were analyzed simultaneously with current data from the corresponding lab and field populations when available, and the statistical signifi- cance of changes in susceptibility was determined using the PROC LOGISTIC procedure (SAS Institute, 2001) at $\alpha=0.05$. Qualitative comparisons were made with the aldrin bioassay data due to the lack of raw data for statistical comparison.

\section{Results}

\subsection{Methyl-parathion bioassays}

Results of probit analyses of the topically applied methyl-parathion bioassays are presented in Table 1 . Methyl-parathion susceptibility was variable across laboratory and field-collected populations with $\mathrm{LD}_{50}$ values in the range from $0.39-7.47 \mathrm{ng} / \mathrm{mg}$ body weight and $0.49-6.52 \mathrm{ng} / \mathrm{mg}$ body weight, respectively. The variation was similar for both field and lab populations and with the results initially reported by Meinke et al. (1998). There were no consistent declines in susceptibility among the lab populations despite being reared in the absence of selection for 5-6 generations. The fieldcollected populations from Buffalo, Clay and Gosper counties all exhibited higher $\mathrm{LD}_{50}$ values relative to the values obtained in 1995 . The laboratory $\left(\mathrm{LD}_{50}=\right.$ $0.39 \mathrm{ng} / \mathrm{mg})$ and field-collected $\left(\mathrm{LD}_{50}=0.49 \mathrm{ng} / \mathrm{mg}\right)$ populations from Saunders County have remained susceptible to methyl-parathion.

\subsection{Aldrin bioassays}

Probit analyses of aldrin bioassays are presented in Table 2 . The susceptibility of the laboratory populations derived from field-collected beetles was in the range between $451.24-1984.4 \mu \mathrm{g} / \mathrm{g}$. The susceptibility of field populations was consistent with the results of laboratory populations, and where direct comparisons were possible (Phelps, Clay, York and Saunders), susceptibilities

Table 1

Susceptibility of laboratory-reared and field-collected adult western corn rootworms to topically applied methyl-parathion

\begin{tabular}{|c|c|c|c|c|c|c|}
\hline \multirow{2}{*}{$\begin{array}{l}\text { Location }^{\text {a }} \\
\text { (Nebraska County) }\end{array}$} & \multicolumn{2}{|c|}{ Meinke et al. (1998) } & \multicolumn{2}{|l|}{ Laboratory } & \multicolumn{2}{|l|}{ Field } \\
\hline & Slope \pm SE & $\mathrm{LD}_{50}(95 \% \mathrm{FL})^{\mathrm{b}}$ & Slope \pm SE & $\mathrm{LD}_{50}(95 \% \mathrm{FL})^{\mathrm{b}}$ & Slope \pm SE & $\mathrm{LD}_{50}(95 \% \mathrm{FL})^{\mathrm{b}}$ \\
\hline Gosper & $3.4 \pm 0.4$ & $0.72(0.4-1.2)$ & - & - & $1.3 \pm 0.7$ & $2.53(2.12 \pm 3.02)$ \\
\hline Phelps1 & $2.6 \pm 0.3$ & $3.97(3.3-4.9)$ & $1.9 \pm 0.2$ & $7.14(5.91 \pm 8.57)$ & - & - \\
\hline Phelps 2 & $2.9 \pm 0.3$ & $8.08(6.7-10.0)$ & $1.8 \pm 0.1$ & $6.49(5.36 \pm 7.80)$ & $2.4 \pm 0.7$ & $4.76(3.98 \pm 5.67)$ \\
\hline Buffalo & $3.0 \pm 0.3$ & $0.82(0.7-1.0)$ & - & - & $1.4 \pm 0.8$ & $6.18(5.18 \pm 7.35)$ \\
\hline Clay & $3.6 \pm 0.4$ & $0.69(0.4-0.9)$ & $2.2 \pm 0.1$ & $0.44(0.36 \pm 0.52)$ & $1.3 \pm 0.2$ & $2.34(1.95 \pm 2.80)$ \\
\hline Hamilton & $2.6 \pm 0.3$ & $3.95(3.0-5.3)$ & - & - & $2.4 \pm 0.8$ & $6.52(5.47 \pm 7.77)$ \\
\hline York & $2.7 \pm 0.2$ & $6.11(5.2-7.1)$ & $1.0 \pm 0.2$ & $7.47(6.19 \pm 8.97)$ & $1.3 \pm 0.8$ & $5.88(4.93 \pm 7.00)$ \\
\hline Saunders & $4.6 \pm 0.6$ & $0.75(0.7-0.9)$ & $1.3 \pm 0.3$ & $0.39(0.32 \pm 0.47)$ & $1.0 \pm 0.1$ & $0.49(0.40 \pm 0.59)$ \\
\hline Dixon & $4.2 \pm 0.6$ & $0.78(0.7-0.9)$ & - & - & $1.0 \pm 0.7$ & $0.72(0.60 \pm 0.85)$ \\
\hline
\end{tabular}

$\mathrm{LD}_{50}$ values derived from collections obtained from the same field or from within $30 \mathrm{~km}$ of the original collection.

${ }^{\mathrm{a}}$ For each population, $n=250-300$.

${ }^{\mathrm{b}}$ Nanograms of methyl-parathion per milligram insect body weight. 
Table 2

Susceptibility of laboratory-reared and field-collected adult western corn rootworms to topically applied aldrin

\begin{tabular}{|c|c|c|c|c|c|}
\hline \multirow[t]{2}{*}{ Location $^{\mathrm{a}}$} & \multirow[t]{2}{*}{$\begin{array}{l}\text { Ball and Weekman } \\
\text { (1963) }\end{array}$} & \multicolumn{2}{|c|}{ Laboratory } & \multicolumn{2}{|l|}{ Field } \\
\hline & & Slope & $\mathrm{LD}_{50}(95 \% \mathrm{FL})^{\mathrm{b}}$ & Slope & $\mathrm{LD}_{50}(95 \% \mathrm{FL})^{\mathrm{b}}$ \\
\hline Gosper & - & - & - & $1.9 \pm 0.3$ & $782.42(608.1-1008.1)$ \\
\hline Phelps & 2295.6 & - & - & $1.7 \pm 0.2$ & $1216.2(947.8-1563.7)$ \\
\hline Phelps 2 & 2295.6 & $1.6 \pm 0.2$ & $644.8(350.1-1176.9)$ & - & - \\
\hline Buffalo & 4476.9 & - & - & $1.2 \pm 0.1$ & $715.66(561.3-911.4)$ \\
\hline Clay & 1099.8 & $1.4 \pm 0.2$ & $546.12(296.2-918.4)$ & $0.3 \pm 0.2$ & $699.35(545.1-897.6)$ \\
\hline Hamilton & - & - & - & $1.6 \pm 0.2$ & $675.50(527.2-866.8)$ \\
\hline York & 1525.7 & $1.4 \pm 0.2$ & $743.88(408.3-1351.2)$ & $1.7 \pm 0.2$ & $433.26(335.5-558.2)$ \\
\hline Saunders & 382.3 & $0.4 \pm 0.3$ & $451.24(231.4-798.4)$ & $1.7 \pm 0.2$ & $430.48(333.1-555.4)$ \\
\hline Dixon & - & - & - & $1.8 \pm 0.3$ & $386.36(297.6-499.3)$ \\
\hline Pennsylvania & $2078.0^{\mathrm{c}}$ & $2.1 \pm 0.2$ & $1984.4(1064-3976.6)$ & - & - \\
\hline Illinois & - & $0.9 \pm 0.5$ & $1691.3(910.5-3207.7)$ & - & - \\
\hline $\begin{array}{l}\text { Non-diapausing } \\
\text { colony }\end{array}$ & - & $1.0 \pm 0.1$ & $9.72(4.35-19.6)$ & - & - \\
\hline
\end{tabular}

$\mathrm{LD}_{50}$ values derived from laboratory and field populations obtained from the same county as the historical collection.

${ }^{\mathrm{a}}$ All locations represent Nebraska Counties except the Pennsylvania, Illinois and non-diapausing lab colonies: for each population, $n=300-400$.

${ }^{\mathrm{b}}$ Micrograms of aldrin per gram insect body weight.

${ }^{\mathrm{c}}$ Data obtained from Siegfried and Mullin (1989).

of the field and lab populations were not different. The only population that appeared susceptible to aldrin was the non-diapausing laboratory population based on similar $\mathrm{LD}_{50}$ values reported by Ball and Weekman (1962) for apparently susceptible populations. There did appear to be a general decline in the level of resistance associated with the populations from Nebraska relative to the historical $\mathrm{LD}_{50}$ values reported by Ball and Weekman (1962). Most $\mathrm{LD}_{50}$ values reported in 1962 exceeded $1,000 \mu \mathrm{g} / \mathrm{g}$ body weight, while all but one of the values from Nebraska populations (both lab- and fieldderived populations) were less than $1,000 \mu \mathrm{g} / \mathrm{g}$. The least tolerant population derived from the field or lab (Saunders) exhibited at least 40 -fold resistance when compared to the non-diapausing laboratory strain. The highest $\mathrm{LD}_{50}$ values were obtained from those populations east of the Mississippi River (Illinois and Pennsylvania), which were more similar in susceptibility to the historical levels originally reported by Ball and Weekman (1963).

\section{Discussion}

The results of this study suggest that resistance to both aldrin and methyl-parathion is relatively stable in the absence of selective pressures both in laboratory and in field populations. Among lab populations of methylparathion resistant western corn rootworms, there were no consistent declines in the levels of resistance in any of the seven populations where direct comparisons with initial field assessments were possible. Among field populations, resistance remained consistently high among populations previously identified as resistant. However, in at least three areas previously identified as being susceptible (Clay, Gosper and Buffalo counties), significantly increased resistance was observed. Adult management programs were still widely practiced in both Buffalo and Gosper counties after these 1995 data were collected (L.J.M., unpublished), and the increased $\mathrm{LD}_{50}$ values are likely the result of selection from exposure to aerially applied methyl-parathion. In contrast, the Clay County collections were obtained from areas where adult management has never been commonly practiced and where crop rotation and soil insecticides have been the most common management practices (L.J.M., unpublished). Given the close proximity of Clay County to areas where resistance has been previously documented, these results suggest not only that resistance is relatively stable, but that resistance alleles have increased in frequency even in the absence of strong selective pressures. Such an increase in resistance frequency indicates that the genes conferring resistance to methyl-parathion do not possess a strong fitness disadvantage and is consistent with an incompletely dominant pattern of resistance inheritance (Parimi et al., 2003). This conclusion is supported by the observation that resistance to methyl-parathion in western corn rootworms is not associated with strong fitness costs (Stebbing, 2003).

Results of aldrin bioassays indicate the presence of high levels of resistance in both the laboratory-reared and field-collected adult western corn rootworms. Aldrin resistance has remained consistently high among field populations over the four decades since aldrin resistance was first reported and with drastically reduced 
selective pressures since the chemical class was banned in 1972. However, there was considerable variation in resistance levels and a general decline in resistance among Nebraska populations. If resistance to cyclodienes were associated with a selective disadvantage for resistant phenotypes in the absence of the insecticide, the frequency of resistance alleles in natural populations will decline over time following the cessation of insecticide usage (McKenzie, 1996). In other species where resistance to cyclodienes has been tracked over time after the insecticides were no longer in use, significant declines in resistance have been observed (McKenzie, 1996). In the case of the sheep blow fly, Lucilia cuprina, a dramatic decline in resistance phenotype frequency was observed within the first 5 years after removal of the chemical for blowfly control (Hughes and McKenzie, 1987).

Given that the western corn rootworm is univoltine throughout its distribution, it is possible that there has simply not been enough time for resistance to have declined significantly. The only population to exhibit complete susceptibility to aldrin was the non-diapause laboratory strain. This strain was derived from a field collection made in an area where resistance was reported to have been present at the time of collection (Metcalf, 1986). Because up to 4 generations of the non-diapause strain can be reared in the laboratory in a single year, slight fitness disadvantages may have been manifested in the loss of resistance over a shorter period of time relative to field populations. It should also be noted that the non-diapause population has likely undergone a rather restrictive genetic bottle-neck during selection for the non-diapause trait. Therefore, the genes conferring resistance could have been lost during selection for the non-diapause trait and are unrelated to possible fitness disadvantages.

Evidence for selection against resistant phenotypes is inferred from changes in the frequency of resistance in natural populations following changing patterns of insecticide use. The results of the present study suggest strongly that such fitness disadvantages associated with both cyclodiene resistance and methyl-parathion resistance are relatively minor.

\section{Acknowledgements}

Our appreciation is extended to Jim Brown and Kathryn Sterling for their assistance in beetle rearing and collections. Partial funding for this project was provided by USDA-ARS specific cooperative agreement 58-5447-6-116 and the USDA Initiative for Future Agricultural and Food Science (Grant \#00-521039699). This is journal series No. 14901 of the University of Nebraska Agricultural Research Division and contribution No. 1205 of the Department of Entomology.

\section{References}

Ball, H.J., 1981. Larval and adult control recommendations and insecticide resistance data for corn rootworms in Nebraska (1948-1981). Report 3. The Agricultural Experiment Station, University of Nebraska-Lincoln.

Ball, H.J., Hill, R.E., 1953. You can control corn rootworm. Nebraska Export Station Quart. Winter 1952-53, Nebraska Agricultural Export Station, Lincoln, Nebraska.

Ball, H.J., Roselle, R.E., 1954. You can control corn rootworms. University of Nebraska Extended Circular 1567.

Ball, H.J., Weekman, G.T., 1962. Insecticide resistance in the adult western corn rootworm in Nebraska. J. Econ. Entomol. 55, 439-441.

Ball, H.J., Weekman, G.T., 1963. Differential resistance of corn rootworms to insecticides in Nebraska and adjoining states. J. Econ. Entomol. 56, 553-555.

Branson, T.F., 1976. The selection of a non-diapausing strain of Diabrotica virgifera (Coleoptera: Chrysomelidae). Entomol. Exp. Appl. 19, 148-154.

Finney, D.J., 1971. Probit Analysis. Cambridge University Press, England.

Hughes, P.B., McKenzie, J.A., 1987. Insecticide resistance in the Australian sheep blowfly, Lucilia cuprina: Speculation, science and strategies. In: Ford, M.G., Holloman, D.W., Khambay, B.P.S., Sawicki, R.M. (Eds.), Combating Resistance to Xenobiotics. Biological and Chemical Approaches. Ellis Horwood, UK, pp. $162-177$.

Jackson, J.J., 1985. Diabrotica spp. Volume 1. In: Singh, P., Moore, R.F. (Eds.), Handbook of Insect Rearing. Elsevier Science Publishers, Amsterdam, The Netherlands, pp. 237-254.

LeOra Software, 1987. POLO-PC. A user's guide to probit analysis or logit analysis. LeOra Software, Berkeley, CA.

Mayo, Z.B., Peters, L.L., 1978. Planting vs. cultivation time applications of granular soil insecticides to control larvae of corn rootworm in Nebraska. J. Econ. Entomol. 71, 801-803.

McKenzie, J.A., 1996. Ecological and Evolutionary Aspects of Insecticide Resistance. Academic Press, San Diego.

Meinke, L.J., Siegfried, B.D., Wright, R.J., Chandler, L.D., 1998. Adult susceptibility of Nebraska populations of western corn rootworm to selected insecticides. J. Econ. Entomol. 91, 594-600.

Metcalf, R.L., 1986. The ecology of insecticides and the chemical control of insects. In: Kogan, M. (Ed.), Ecological Theory and Integrated Pest Management Practice. Wiley, NY, pp. 251-297.

Muma, M.H., Hill, R.E., Hixson, E., 1949. Soil treatments for corn rootworm control. J. Econ. Entomol. 42, 822-824.

Parimi, S., Scharf, M.E., Meinke, L.J., Chandler, L.D., Siegfried, B.D., 2003. Inheritance of methyl-parathion resistance in Nebraska western corn rootworm populations (Coleoptera: Chrysomelidae). J. Econ. Entomol. 96, 131-136.

Pruess, K.P., Witkowski, J.F., Raun, E.S., 1974. Population suppression of western corn rootworm by adult control with ULV Malathion. J. Econ. Entomol. 67, 541-545.

Roselle, R.E., Anderson, L.W., Simpson, R.G., Webb, M.C., 1959. Annual Report for 1959, Cooperative Extension Work in Entomology, Lincoln, Nebraska.

Roselle, R.E., Anderson, L.W., Simpson, R.C., Bergman, P.W., 1960. Annual Report for 1960, Cooperative Extension Work in Entomology, Lincoln, Nebraska.

Roselle, R.E., Anderson, L.W., Bergman, P.W., 1961. Annual Report for 1961, Cooperative Extension Work in Entomology, Lincoln, Nebraska.

SAS Institute, 2001. SAS/STAT User's Guide, SAS Institute, Cary, NC.

Siegfried, B.D., Mullin, C.A., 1989. Influence of alternative host plant feeding on aldrin susceptibility and detoxification enzymes in 
western and northern corn rootworms. Pestic. Biochem. Physiol. $35,155-164$.

Stebbing, J., 2003. Characterization of selected life history traits of western corn rootworm, Diabrotica virgifera virgifera, LeConte populations resistant and susceptible to methyl-parathion. Ph.D. Dissertation, University of Nebraska-Lincoln.

Tabashnik, B.E., 1990. Modeling and evaluation of resistance management tactics. In: Roush, R.T., Tabashnik, B.E. (Eds.), Pesticide Resistance in Arthropods. Chapman and Hall, NY, pp. 153-182.
Wright, R.J., Meinke, L.J., Siegfried, B.D., 1996. Corn rootworm management and insecticide resistance management. In: Proceedings 1996 Crop Protection Clinic. Univ. Nebr. Coop. Ext., pp. $45-53$.

Zhou, X., Scharf, M.E., Parimi, S., Meinke, L.J., Wright, R.J., Chandler, L.D., Siegfried, B.D., 2002. Diagnostic assays based on esterase-mediated resistance mechanisms in western corn rootworms (Coleoptera: Chrysomelidae). J. Econ. Entomol. 95, 1261-1266. 